\title{
Apple polysaccharides induce apoptosis in colorectal cancer cells
}

\author{
DIAN ZHANG ${ }^{1,2}$, YANG SUN ${ }^{2}$, ZHENGGANG YUE $^{2}$, QIAN LI $^{2}$, JIN MENG $^{2}$, JUNAJUAN LIU $^{2}$, \\ XIANG HEKONG ${ }^{3}$, FENGLIANG JIANG ${ }^{1}, \mathrm{MAN} \mathrm{MI}^{1}, \mathrm{LI} \mathrm{LIU}^{2}$ and QIBING MEI ${ }^{2}$ \\ ${ }^{1}$ Department of Pathogen Biology and Immunology, Xi'an Medical College, Xi'an 710021; ${ }^{2}$ Key Laboratory \\ of Gastrointestinal Pharmacology of Chinese Materia Medica of the State Administration of Traditional Chinese Medicine, \\ Department of Pharmacology, School of Pharmacy, Fourth Military Medical University, Xi'an 710032; \\ ${ }^{3}$ Faculty of Life Sciences, Northwestern Polytechnical University, Xi'an 710072, Shaanxi, P.R. China
}

Received December 14, 2011; Accepted January 30, 2012

DOI: $10.3892 / \mathrm{ijmm} .2012 .953$

\begin{abstract}
Certain components of apples have been shown to prevent cancer growth and impede cancer progression. We hypothesized that extracted apple polysaccharides (APs) might, therefore, have anticancer effects, through a mechanism involving the induction of apoptosis in cancer cells, partly via the NF- $\kappa \mathrm{B}$ pathway. Two human colorectal cancer (CRC) cell lines, HT-29 and SW620, were exposed to different concentrations of APs $(0.01,0.1$ or $1 \mathrm{mg} / \mathrm{ml})$. Cell apoptosis was measured by the 3-(4,5-dimethylthiazol-2-yl)2,5-diphenyltetrazolium bromide assay by flow cytometry and incorporation of 5'-bromodeoxyuridine (BrdU) into DNA to identify the proliferating cell fraction, using fluorescence microscopy in vitro. The protein levels of NF- $\kappa \mathrm{B} / \mathrm{p} 65, \mathrm{I}-\kappa \mathrm{B} \alpha$, $\mathrm{pI}-\kappa \mathrm{B} \alpha, \mathrm{Bax}, \mathrm{Bcl}-\mathrm{xl}$ and Bcl-2 were evaluated by western blotting. The target sites of APs on CRC cells were assessed by flow cytometry. At concentrations of 0.1 and $1 \mathrm{mg} / \mathrm{ml}$, APs showed apoptosis-inducing effects, increased expressions of Bax, nuclear p65 and cytoplasmic $\mathrm{pI}-\kappa \mathrm{B} \alpha$, and decreased expressions of Bcl-2, Bcl-xl and cytoplasmic I- $\kappa \mathrm{B} \alpha$. APs induced apoptosis by slightly activating the $\mathrm{NF}-\kappa \mathrm{B}$ pathway; the AP target site could be the Toll-like receptor 4 on the cell membrane. These results demonstrate the potential of APs as agents for clinical prevention and treatment of CRC.
\end{abstract}

\section{Introduction}

Colorectal cancer (CRC) is one of the leading causes of cancer-related morbidity and mortality, with approximately

Correspondence to: Dr Qibing Mei, Department of Pharmacology, School of Pharmacy, Fourth Military Medical University, Xi'an 710032, Shaanxi, P.R. China

E-mail: qbmei@fmmu.edu.cn

Key words: apoptosis, colorectal cancer cells, apple polysaccharides, $\mathrm{NF}-\kappa \mathrm{B}$ pathway half a million deaths and over 1 million new cases estimated per year, mostly in western and well-developed countries $(1,2)$. Dietary changes may prevent $70-80 \%$ of CRC cases $(3,4)$. The most potent agents used for cancer prevention and treatment should be nontoxic, such as those that are naturally present in foods.

As is well known, regular consumption of fruits and vegetables is inversely associated with colorectal cancer risk. Apples have been identified as chemopreventive agents and are linked to a reduced risk of cancer $(5,6)$. We therefore, observed the effect of apple polysaccharides (AP) on CRC cell apoptosis and investigated their anticancer mechanism.

The transcription factor $\mathrm{NF}-\kappa \mathrm{B}$ exists in almost all cell types, and is critically involved in the regulation of apoptosis (7). The aim of the present study was to determine whether APs mediate an antitumor effect, and, if so, to investigate whether the relevant cell mechanism involved the $\mathrm{NF}-\kappa \mathrm{B}$ pathway.

\section{Materials and methods}

Reagents. Cytoplasmic and nuclear extracts were purchased from Pierce Biotechnology, Inc. (USA). Lipopolysaccharides (LPS) were obtained from Escherichia coli 055:B5 F8666-fluorescein isothiocyanate (FITC) conjugate, 5'-bromodeoxyuridine (BrdU) was from Sigma (St. Louis, MO).

Cell culture. HT-29 and SW620 cell lines as well as human intestinal epithelial cells (HIEC) were obtained from the American Type Culture Collection. The HT-29 and SW620 cell lines were separately cultured in RPMI-1640 medium containing $10 \%$ fetal bovine serum (FBS); HIEC were cultured in Dulbecco's modified Eagle's medium with $10 \%$ FBS and $0.2 \mathrm{U} / \mathrm{ml}$ insulin, with a mixture of antibiotics $(100 \mathrm{U} / \mathrm{ml}$ penicillin $\mathrm{G}$ and $100 \mu \mathrm{g} / \mathrm{ml}$ streptomycin); all cells were incubated at $37^{\circ} \mathrm{C}$ in an atmosphere of $95 \%$ oxygen and $5 \% \mathrm{CO}_{2}$.

Preparation of AP. Apples were purchased from Sanyuan (Shaanxi, China). APs were extracted according to previously published methods (8). Briefly, residues were separated from squeezed apple juice, boiled with ethanol to remove alcohol-soluble components, and then boiled with water to 


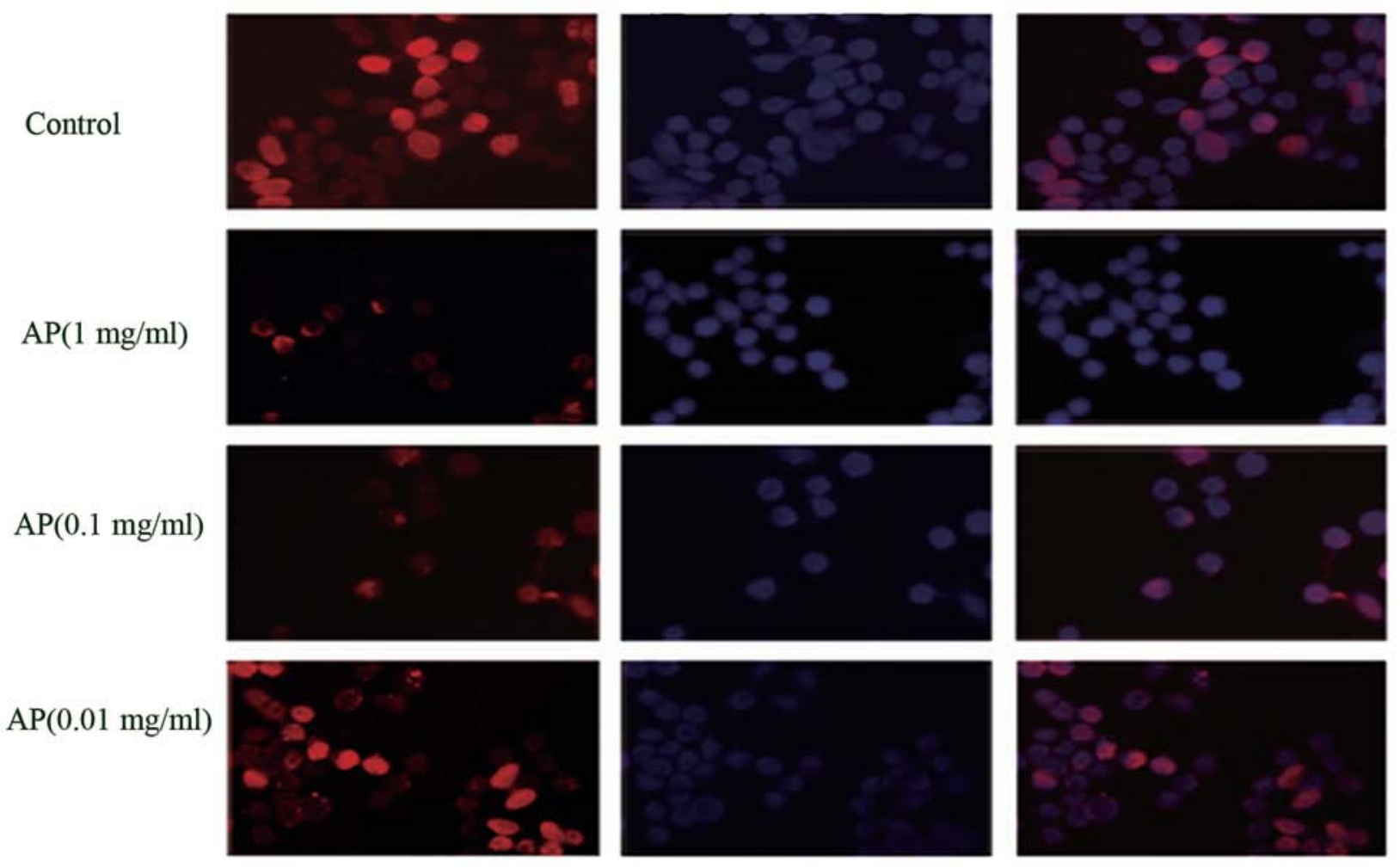

Figure 1. Labeling and analysis of proliferating SW620 cells by BrdU immunocytochemistry. CRC cells in culture were labeled with BrdU. BrdU-labeled DNA was detected with anti-BrdU antibody and goat anti-mouse IgG-TRITC, as described in Materials and methods. The labeled cell preparation (bright red nuclei) was analyzed under a fluorescence microscope.

extract polysaccharides. Extract proteins were removed by the Sevag reagent (9). After removing proteins and pigment, we dialyzed, concentrated and lyophilized the remainder. The AP sugar content was $70.15 \%$.

BrdU immunocytochemistry. The CRC cells on coverslips were grown in RPMI-1640 medium containing BrdU (3 $\mu \mathrm{g} /$ $\mathrm{ml}$ ), and incubated at $37^{\circ} \mathrm{C}, 5 \% \mathrm{CO}_{2}$ for $\sim 4 \mathrm{~h}$. Cells were fixed with $4 \%$ paraformaldehyde in phosphate-buffered saline (PBS) for $15 \mathrm{~min}$ at $37^{\circ} \mathrm{C}$, and then blocked with $5 \%$ bovine serum albumin (BSA) in PBS for $1 \mathrm{~h}$. Next, cells were incubated with $2 \mathrm{~N} \mathrm{HCl}$ for 30 min to denature DNA and then incubated with rat anti-BrdU antibody (rabbit no. 7074S, Cell Signaling Technology, Beverly, MA) at 1:200 dilution in blocking serum overnight at $4^{\circ} \mathrm{C}$. After rinsing, cells were treated with TRITCconjugated goat anti-mouse IgG secondary antibody (Dingguo Biotechnology, Beijing, China) for $1 \mathrm{~h}$. Nuclei were stained with 4',6'-diamidino-2-phenylindole (DAPI) and examined under a fluorescence microscope.

Flow cytometric analysis. The HT-29 and SW620 cells were grown to $5 \times 10^{4}$ in 6 -well plates and cultured with AP at 0.01 , 0.1 or $1 \mathrm{mg} / \mathrm{ml}$ for $48 \mathrm{~h}$. Cells were harvested and washed in ice-cold PBS, and FITC Annexin V and propidium iodide (PI) were added. Apoptosis was analyzed by flow cytometry. All fluorescence and laser light scatter measurements were conducted with linear signal-processing electronics.

We then examined the effects of preincubation of CRC cells with AP on LPS-FITC binding. Different concentrations $(0.01,0.1$ or $1 \mathrm{mg} / \mathrm{ml})$ of AP were incubated with HT-29 and
SW620 cells, in $5 \% \mathrm{CO}_{2}$ and $95 \%$ air for $60 \mathrm{~min}$ at $37^{\circ} \mathrm{C}$. A fixed concentration of LPS-FITC $(10 \mu \mathrm{g} / \mathrm{ml})$ was added and incubation continued for another $60 \mathrm{~min}$. After incubation, cells were washed three times with PBS to remove non-conjugated FITC-LPS. Fluorescence intensity (FI) was determined by flow-cytometric analysis.

Protein extraction and western blot analysis. The CRC cells were cultured in 100-ml cell culture bottles with AP at 0.01 , 0.1 or $1 \mathrm{mg} / \mathrm{ml}$ for $48 \mathrm{~h}$. Cells were used for whole cell-free extracts and nuclear/cytoplasmic protein separation or stored at $-80^{\circ} \mathrm{C}$ for future use. Nuclear and cytoplasmic proteins were isolated with a buffer extraction system and centrifugation according to the manufacturer's recommended protocol. Protein concentrations were determined using BCA reagents with BSA as a standard. Equal amounts of proteins $(40 \mu \mathrm{g})$ were separated by $12 \%$ SDS-PAGE and transferred electrophoretically to nitrocellulose membranes (Pall Corporation, Port Washington, NY, USA). The membranes were blocked with 5\% non-fat dry milk in PBS Tween-20 (PBST) for $2 \mathrm{~h}$ at room temperature and subsequently incubated overnight at $4^{\circ} \mathrm{C}$ with primary antibodies: rabbit anti-Bcl-2, Bcl-xl, I- $\kappa \mathrm{B} \alpha$ and $\mathrm{pI}-\kappa \mathrm{B} \alpha$ (Bioworld Technology, Inc., USA) 1:500 dilution; rabbit anti-Bax (Abcam Co., Cambridge, UK) 1:1,000 dilution; and rabbit anti-p65 and anti- $\beta$-actin (Bioworld Technology, Inc.) 1:1200 dilution in 5\% (w/v) BSA. After 3 washes with PBST, membranes were incubated with anti-rabbit secondary antibodies $(1: 7,000)$ for $2 \mathrm{~h}$ at room temperature. After three washes with PBST, signals were detected using the Gel Doc system (Bio-Rad). 
A

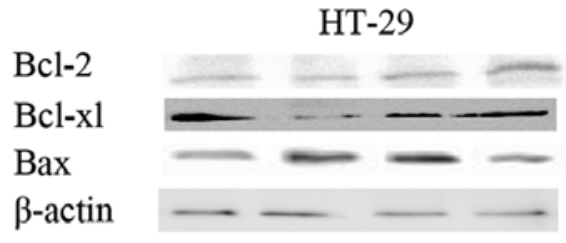

Bcl-2

Bcl-xl

Bax

$\beta$-actin
SW620

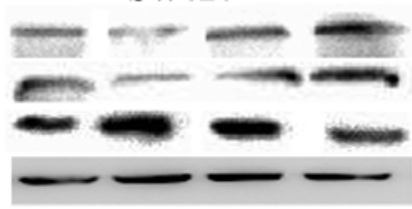

B
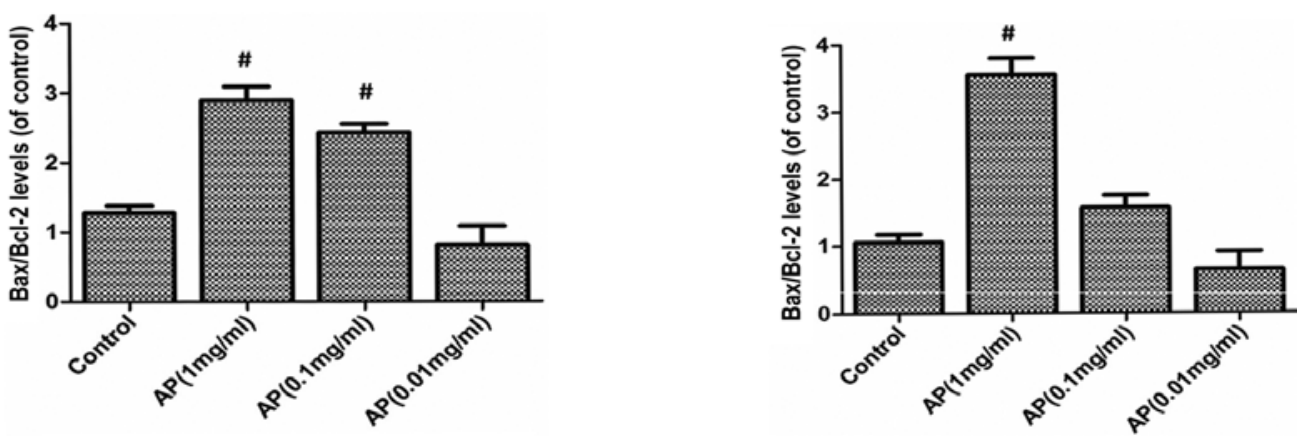

Figure 2. Effects of apple polysaccharides (AP) on Bcl-xl, Bcl-2 and Bax in CRC cells. (A) CRC cells were treated and incubated with different concentrations of AP (0.01-1.0 mg/ml). Western blot analysis was performed to detect the expression of Bcl-xl, Bcl-2 and Bax protein levels as described in Materials and methods. (B) Bax/Bcl-2 ratio, ${ }^{\text {}} \mathrm{P}<0.01$.

Immunofluorescence analysis. The HT-29 and SW620 cells were each grown in 24-well plates seeded with $1 \times 10^{5}$ cells/well and cultured with AP at $0.01,0.1$ or $1 \mathrm{mg} / \mathrm{ml}$, for $24 \mathrm{~h}$. After fixing and washing, cells were incubated for $1 \mathrm{~h}$ at $37^{\circ} \mathrm{C}$ with rabbit antihuman NF- $\kappa$ B p65 antibody. Slides were washed 3 times with $0.05 \%$ Triton $\mathrm{X}-100-\mathrm{PBS}$ solution, then incubated for $1 \mathrm{~h}$ at $37^{\circ} \mathrm{C}$ with goat anti-rabbit IgG TRITC-conjugated secondary antibody. Cells were then washed with PBS and examined under a fluorescence microscope (magnification, $\mathrm{x} 40$ ).

Statistical analysis. Results are expressed as the mean \pm standard deviation (SD); different groups were compared using ANOVA tests. $\mathrm{P}<0.05$ was considered to indicate statistically significant differences.

\section{Results}

Results of high-performance liquid chromatography. The chromatogram of the mixture of monosaccharide derivatives identified the following: 11-phenyl-3-methyl-5-pyrazolone (PMP), mannose, glucuronic acid, galacturonic acid, glucose, galactose and xylose.

The standard curve equation was obtained using the Longzhida workstation (Beijing, China): Ln (Mn, weightaverage molecular weight $)=B_{0}+\left(B_{1} \times t\right)+\left(B_{2} x^{-2}\right)+\left(B_{3} x^{-3}\right)$ where, $B_{0}=10.32789, B_{1}=-4400521, B_{2}, 3=0$ and $t=$ retention time $\left(\mathrm{R}^{2}=0.9995\right)$. Accordingly, the molecular weight of AP was 5,000-10,000 Da.

$A P$ inhibits proliferation of $C R C$. To verify the effects of AP on cell-cycle progression, DNA synthesis was measured by assessing BrdU incorporation; labeled cell preparations were analyzed under a fluorescence microscope (Fig. 1). Results showed proliferating cells (bright red nuclei) within the CRC cell preparation clearly visible under the fluorescence microscope; AP inhibited the growth of CRC cells at the concentrations of 0.1 and $1 \mathrm{mg} / \mathrm{ml}$.

AP induces apoptosis in CRC cells. Western blotting (Fig. 2) showed that AP treatments at 0.1 or $1 \mathrm{mg} / \mathrm{ml}$ for $48 \mathrm{~h}$ increased Bax and decreased Bcl-2 and Bcl-xl expression. Apoptosis was then assessed by flow cytometry (Fig. 3). At 0.1 and $1 \mathrm{mg} / \mathrm{ml}$, APs triggered apoptosis of some CRC cells, but had no effect on HIEC.

Induction of apoptosis by APs correlates with the activation of $N F-\kappa B$. Western blotting showed that treatment with APs at 0.1 or $1 \mathrm{mg} / \mathrm{ml}$ for $48 \mathrm{~h}$ increased the expression of nuclear $\mathrm{p} 65$ and cytoplasmic $\mathrm{pI}-\kappa \mathrm{B} \alpha$, and decreased cytoplasmic I- $\kappa \mathrm{B} \alpha$ expression in HT-29 and SW620 cells, but had no effect on HIEC (Fig. 4).

To determine whether APs could activate NF- $\kappa \mathrm{B}$, we used anti-NF- $\mathrm{B}$ p65 antibody and fluorescence microscopy. Strong fluorescence was predominantly seen in the cytoplasm of untreated HT-29 and SW620 cells (Fig. 5). Following treatment with AP $(0.1$ or $1 \mathrm{mg} / \mathrm{ml}$, for $24 \mathrm{~h})$, cytoplasmic fluorescence tended to decrease while nuclear fluorescence sharply increased, suggesting translocation of activated NF- $\kappa$ B protein from the cytoplasm to the nucleus.

Effect of APs on the binding of FITC-LPS in HT-29 and SW620 cells. To evaluate the target sites of AP, FITC-LPS (10 $\mu \mathrm{g} / \mathrm{ml})$ was used to compete with AP in binding to the Toll-like receptor-4 (TLR4). The studies were performed with AP in the presence or absence of FITC-LPS in SW620 and HT-29 cells and assessed by flow cytometry. As the results demonstrate, preincubation of cells with AP (0.01, 0.1 or $1 \mathrm{mg} / \mathrm{ml}$ ) resulted in a dose-dependent inhibition of LPS-FITC binding in CRC cells (Fig. 6); APs localized at the same position as TLR4 on the cell membrane. The data 


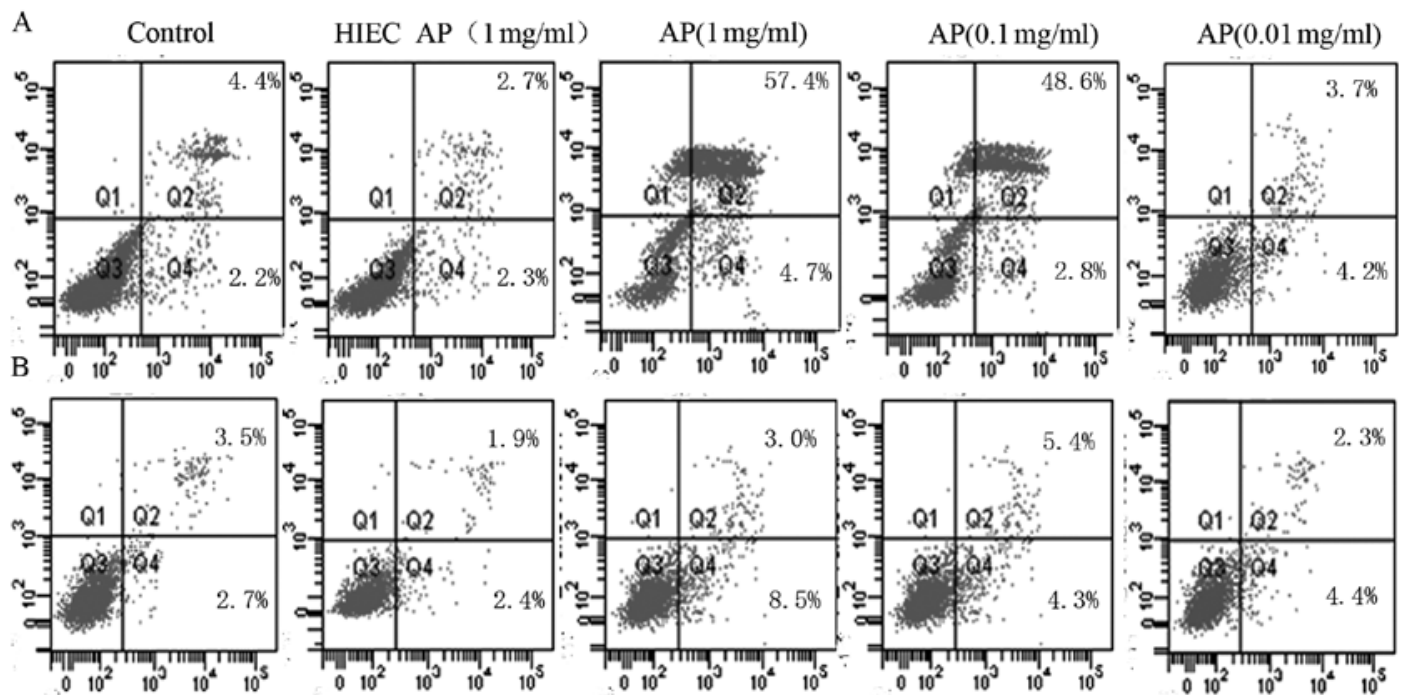

Figure 3. Flow cytometric analysis for apoptosis of human CRC cells. Q1 indicates cells undergoing necrosis; Q2, cells at the end stage of apoptosis; Q3, cells that are viable, or no measurable apoptosis. Q4, cells undergoing apoptosis. (A) HT-29 cells; (B) SW620 cells.

A
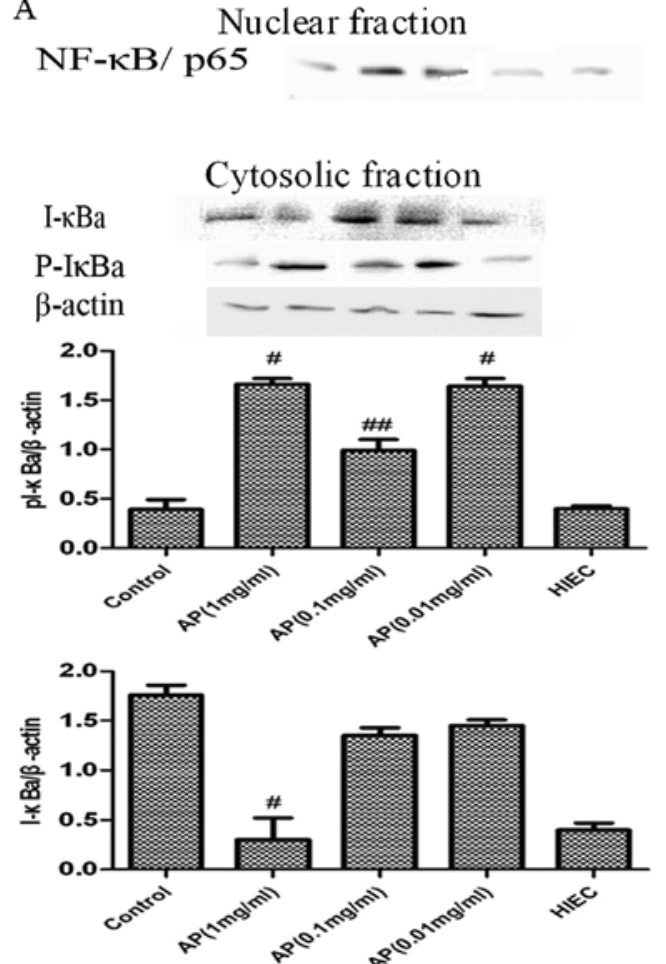

B p $65 \mathrm{NF}-\kappa \mathrm{B} / \mathrm{p} 65$

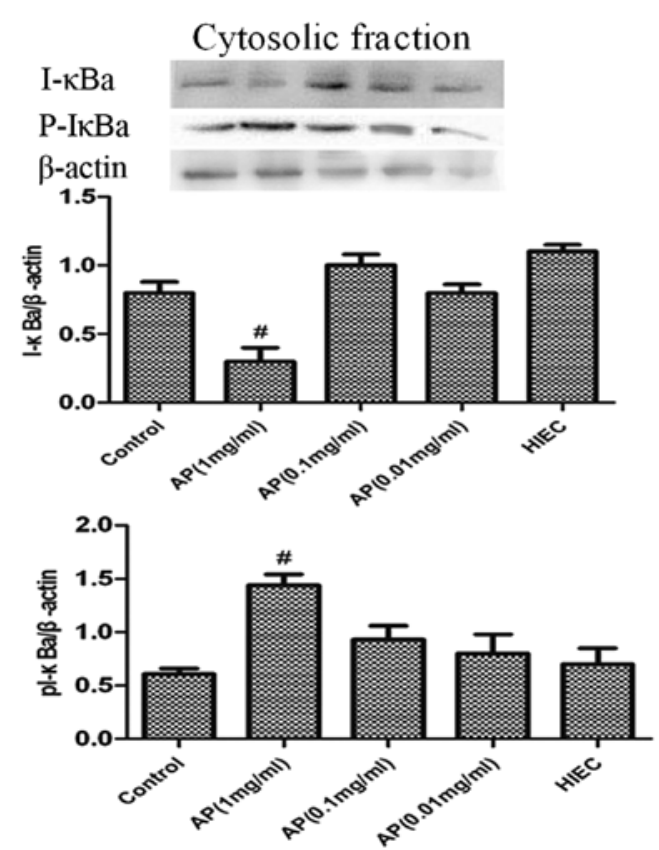

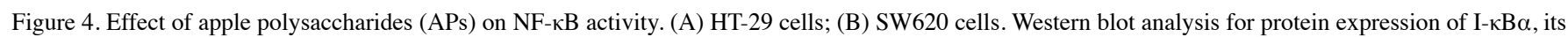
$\mathrm{p}-\mathrm{I} \kappa \mathrm{B} \alpha$ in the cytosolic fraction and $\mathrm{p} 65$ in the nuclear fraction of HT-29, SW620 and HIEC cells. Compared with control group $\left({ }^{\#} \mathrm{P}<0.01\right.$ and $\left.{ }^{\#} \mathrm{P}<0.05\right)$.

revealed a marked inhibitory effect of AP on FITC-LPS binding to TLR4 at $37^{\circ} \mathrm{C}$.

\section{Discussion}

Numerous studies have shown that consumption of fruits and vegetables can prevent cancer occurrence. As procyanidins and triterpenoids from apples have been shown to decrease CRC incidence (6), we examined the effects of APs on CRC apoptosis (an important anticarcinogenic process). A common approach for assessing proliferative activity involves measuring DNA content via BrdU incorporation into growing DNA strands $(10,11)$. Results of BrdU immunocytochemistry, flow cytometry and western blotting showed that APs increased apoptosis in CRC cells in a dose-dependent manner, but had no effect on HIEC.

As the transcription factor NF- $\mathrm{\kappa B}$ mediates cellular growth properties and apoptosis, we hypothesized that the NF- $\kappa \mathrm{B}$ signaling pathway may be a target for AP; NF- $\mathrm{kB}$ is composed of homo- and heterodimers of the Rel family proteins, namely 
DAPI
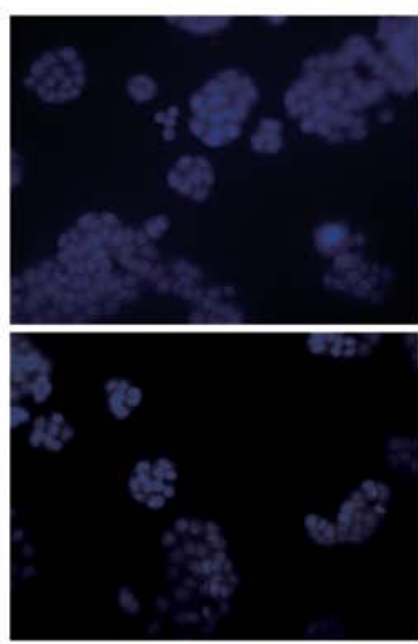

$\mathrm{AP}(1 \mathrm{mg} / \mathrm{ml})$

$\mathrm{AP}(0.1 \mathrm{mg} / \mathrm{ml})$

$\mathrm{AP}(0.01 \mathrm{mg} / \mathrm{ml})$

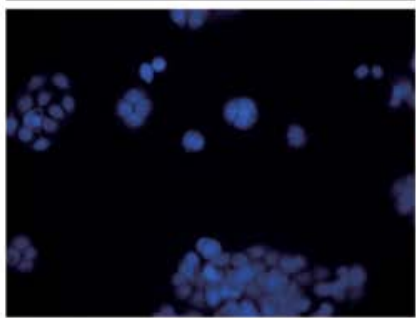

p65
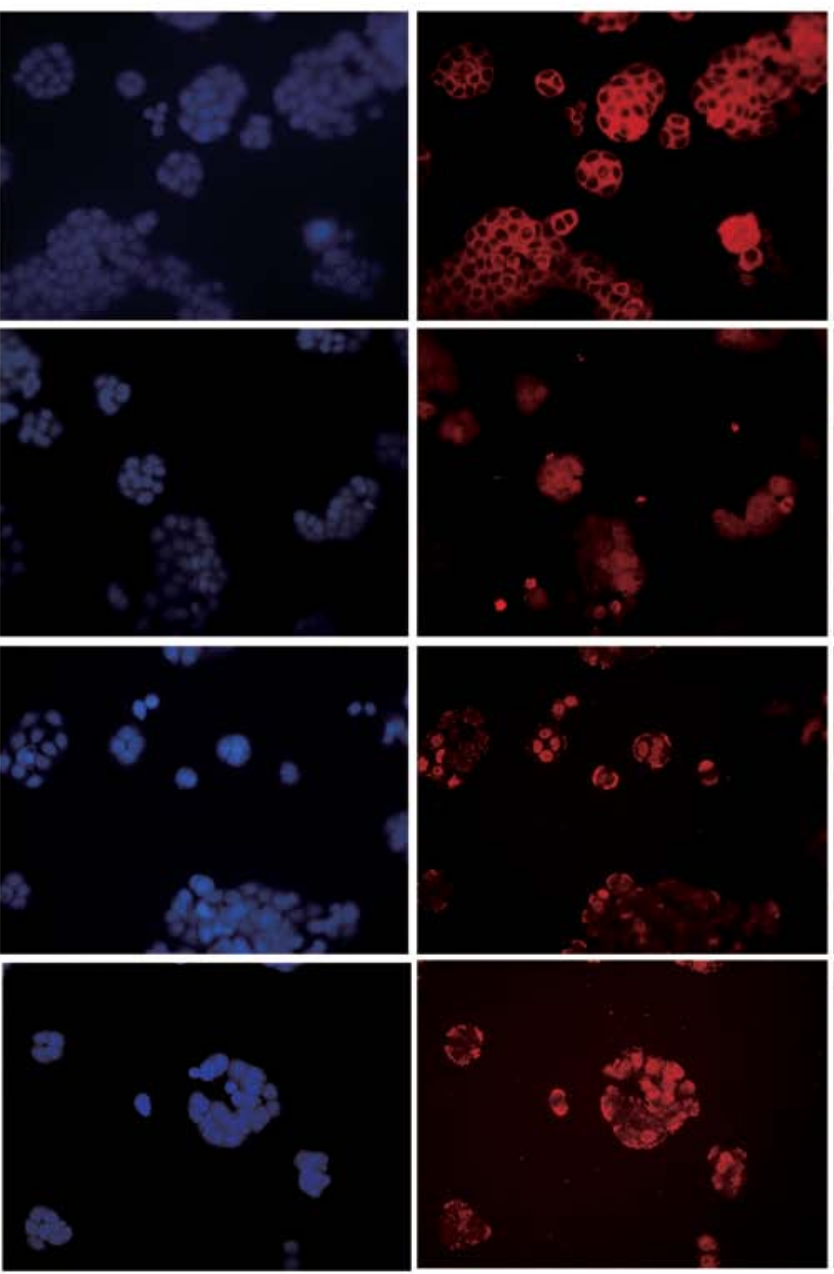
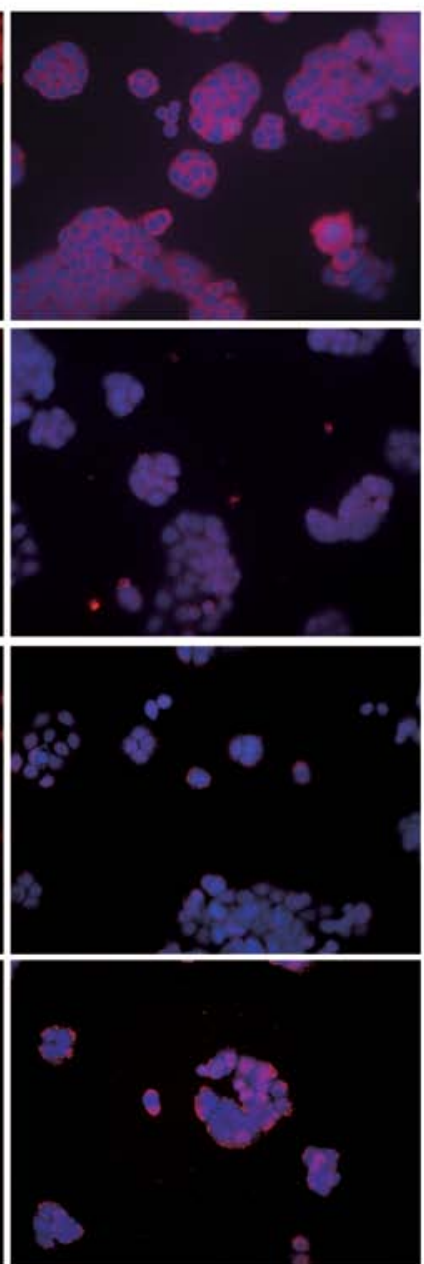

Figure 5. Apple polysaccharides (APs) induce translocation of the p65 from cytoplasm to the nucleus in CRC cells as detected by immunofluorescence microscopy. APs (1.0-0.01 mg/ml) was added $24 \mathrm{~h}$ before the cells were fixed for immunolabeling. In the untreated cells, the fluorescence was concentrated in the cytoplasm, whereas after incubation with AP (1 and $0.1 \mathrm{mg} / \mathrm{ml})$ for $24 \mathrm{~h}$, the fluorescence was clearly observed in the nucleus.

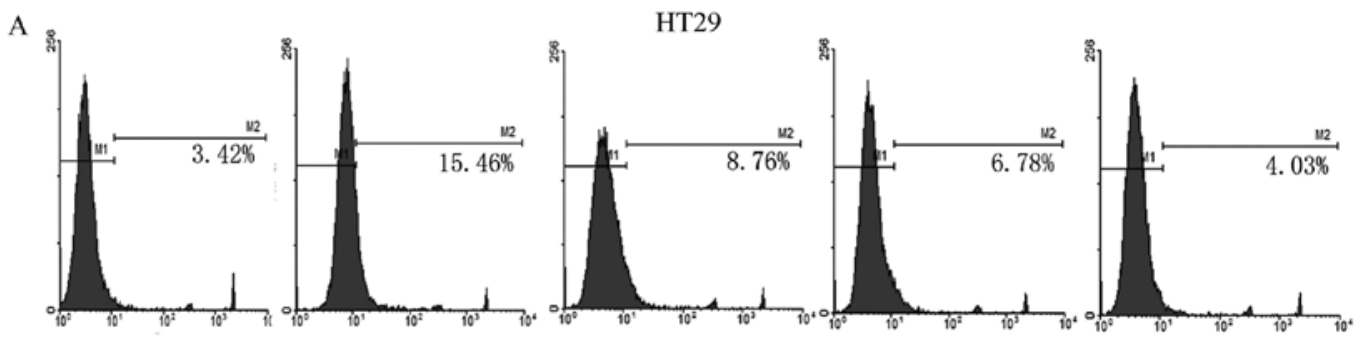

B

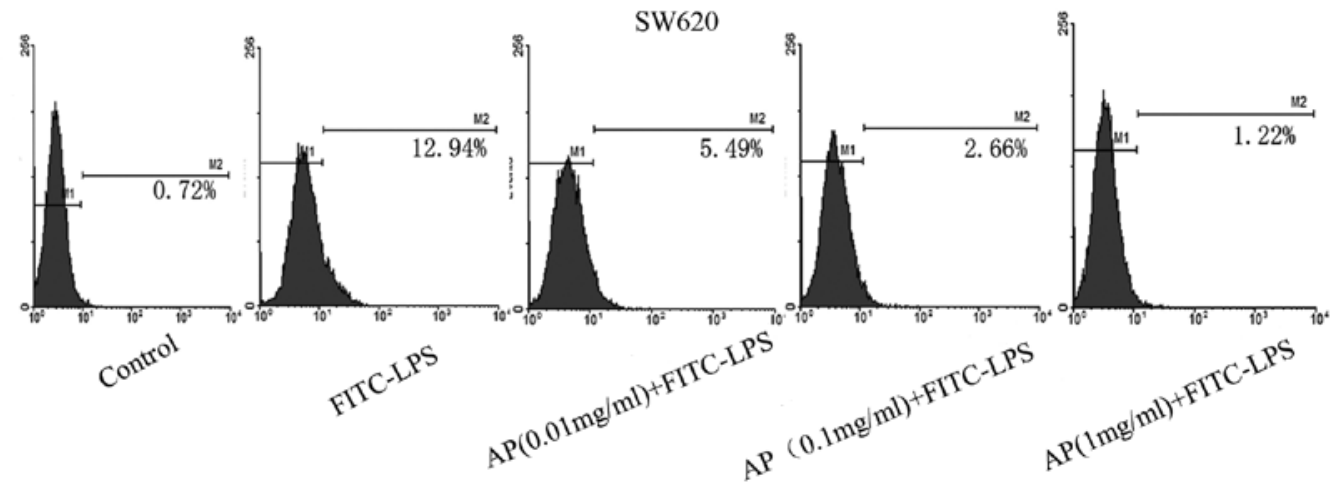

Figure 6. Effects of apple polysaccharides (APs) on the binding of FITC-LPS in HT-29 or SW620 cells by flow cytometric analysis. HT-29 or SW620 cells were incubated with AP (1.0-0.01 mg/ml) at $37^{\circ} \mathrm{C}$ for $60 \mathrm{~min}$, followed by incubation with FITC-LPS (10 $\left.\mu \mathrm{g} / \mathrm{ml}\right)$ for another $60 \mathrm{~min}$. The cells were then washed with PBS for three times and the fluorescence intensity (FI) was determined using flow cytometric analysis. (A) HT-29 cells; (B) SW620 cells. 


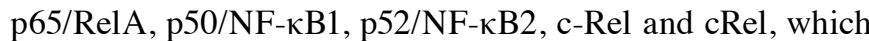
are sequestered in the cytoplasm by physical association with inhibitory proteins referred to as I $\mathrm{KB}(12,13)$. The bestcharacterized member of this family is $\mathrm{I}-\kappa \mathrm{B} \alpha$. Upon exposure to proinflammatory cytokines and microbial products, such as bacterial LPS, TNF- $\alpha$ and IL- $1, \mathrm{I}-\kappa \mathrm{B} \alpha$ is rapidly phosphorylated by the I $\mathrm{B}$ kinase (IKK) complex and degraded. This allows $\mathrm{NF}-\kappa \mathrm{B}$ to translocate to the nucleus, where it binds to regulatory elements within the promoter region of the target genes. Thus, the NF- $\kappa \mathrm{B}$ signaling pathway plays a critical role in the regulation of the inflammatory response, the immune system, cellular proliferation, apoptosis, and antitumor effects of non-steroidal anti-inflammatory drugs (NSAIDs) in the colon (14-18).

When CRC cells were treated with APs $(0.1$ or $1 \mathrm{mg} / \mathrm{ml})$ for $48 \mathrm{~h}, \mathrm{I}-\kappa \mathrm{B} \alpha$ levels were decreased in the cytoplasm, resulting in $\mathrm{NF}-\kappa \mathrm{B}$ nuclear translocation, according to western blot analyses (Fig. 4). Immunofluorescence microscopy also monitored the translocation of activated $\mathrm{NF}-\kappa \mathrm{B}$ from the cytoplasm to the nucleus, but this technique remains primarily qualitative (Fig. 5).

Activation of $\mathrm{NF}-\kappa \mathrm{B}$ is a double-edged sword $(19,20)$, especially with regard to cancer. Whether $N F-\kappa B$ activation is beneficial or harmful for cancer remains controversial. Reportedly, NF- $\kappa \mathrm{B}$ activation suppresses apoptosis (21-23). However, increasing evidence shows that NF- $\kappa \mathrm{B}$ transcription factors are involved in programmed cell death (24-28). We initially observed that apoptotic responses in HT-29 and SW620 cells were partly attributable to modulation of the NF- $\kappa$ B signaling pathway by APs; effects of APs on I- $\kappa \mathrm{B} \alpha$ and p65 were investigated using western blotting and immunofluorescent techniques. From the experiments we concluded that AP-induced apoptosis is partly due to nuclear translocation of $\mathrm{NF}-\kappa \mathrm{B}$.

We then assessed the targets of APs on CRC cells. We used LPS labeled with FITC (FITC-LPS) to compete with AP in binding to TLR4, because LPS is the main ligand of the TLR4. Using flow cytometry, we investigated the effect of APs on FITC-LPS binding in HT-29 and SW620 cells. We demonstrated the inhibitory effect of APs on FITC-LPS binding to TLR4 at $37^{\circ} \mathrm{C}$ (Fig. 6). LPs are toxic, proinflammatory constituents from potential pathogenic bacteria derived from intestinal flora imbalance; LPS-induced NF- $\kappa \mathrm{B}$ signaling pathway activation plays an important role in the development of CRC from chronic bacterial infection (29). Our results show that AP and LPS compete for the same position at the TLR4 on the cell membrane. When APs were combined with LPS, the $\mathrm{NF}-\kappa \mathrm{B}$ signaling pathway was suppressed, while AP alone slightly increased the expression of $N F-\kappa B$ and p65 nuclear proteins, and activated the NF- $\mathrm{B}$ signaling pathway.

In conclusion, APs could induce apoptosis in human CRC cells, partly via the NF- $\kappa \mathrm{B}$ pathway. While the anticarcinogenic activity of APs involves targeting the LPS/TLR4/ $\mathrm{NF}-\kappa \mathrm{B}$ pathway, identifying the precise target requires further research. Our data also show that APs have clinical implications for the prevention of colon cancer.

\section{Acknowledgements}

This study was supported by the National 973 Project of China (2010CB535002).

\section{References}

1. Zhao YS, Wang F, Chang D, et al: Meta-analysis of different test indicators: helicobacter pylori infection and the risk of colorectal cancer. Int J Colorectal Dis 23: 875-882, 2008.

2. Smith RA, Cokkinides V, Brooks D, Saslow D, Shah M and Brawley OW: Cancer screening in the United States, 2011: a review of current American Cancer Society guidelines and issues in cancer screening. CA Cancer J Clin 61: 8-30, 2011.

3. Cummings JH and Bingham SA: Diet and the prevention of cancer. BMJ 317: 1636-1640, 1998.

4. Pan MH, Lai CS, Wu JC and Ho CT: Molecular mechanisms for chemoprevention of colorectal cancer by natural dietary compounds. Mol Nutr Food Res 55: 32-45, 2011.

5. Terry P, Giovannucci E, Michels KB, Bergkvist L, Hansen H, Holmberg $L$ and Wolk A: Fruit, vegetables, dietary fiber, and risk of colorectal cancer. J Natl Cancer Inst 93: 525-533, 2001.

6. Gosse F, Guyot S, Roussi S, Lobstein A, Fischer B, Seiler N and Raul F: Chemopreventive properties of apple procyanidins on human colon cancer-derived metastatic SW620 cells and in a rat model of colon carcinogenesis. Carcinogenesis 26: 1291-1295, 2005.

7. Galardi S, Mercatelli N, Farace MG and Ciafre SA: NF- $\kappa B$ and c-Jun induce the expression of the oncogenic miR-221 and miR-222 in prostate carcinoma and glioblastoma cells. Nucleic Acids Res 39: 3892-3902, 2011.

8. Liu L, Wang ZP, Xu CT, Pan BR, Mei QB, Long Y, Liu JY and Zhou SY: Effects of Rheum tanguticm polysaccharide on TNBSinduced colitis and $\mathrm{CD}^{+}{ }^{+} \mathrm{T}$ cells in rats. World $\mathrm{J}$ Gastroenterol 9: 2284-2288, 2003.

9. Navarini L, Gilli R, Gombac V, Abatangelo A, Bosco M and Toffanin R: Polysaccharides from hot water extracts of roasted Coffea arabica beans: isolation and characterization. Carbohydr Polym 40: 71-81, 1999.

10. Alaimo A, Gorojod RM and Kotler ML: The extrinsic and intrinsic apoptotic pathways are involved in manganese toxicity in rat astrocytoma C6 cells. Neurochem Int 59: 297-308, 2011.

11. Dolbeare F: Bromodeoxyuridine: a diagnostic tool in biology and medicine. Part I: historical perspectives, histochemical methods and cell kinetics. Histochem J 27: 339-369, 1995.

12. Oeckinghaus A and Ghosh S: The NF- $\mathrm{B}$ B family of transcription factors and its regulation. Cold Spring Harb Perspect Biol 3: 1-14, 2009.

13. Westbrook AM, Szakmary A and Schiestl RH: Mechanisms of intestinal inflammation and development of associated cancers: lessons learned from mouse models. Mutat Res 705: 40-59, 2010.

14. Purnak $\mathrm{T}$ and Ozaslan E: Molecular basis of colorectal cancer. $\mathrm{N}$ Engl J Med 362: 1246-1247, 2010.

15. O'Connor PM,Lapointe TK, Beck PL and Buret AG: Mechanisms by which inflammation may increase intestinal cancer risk in inflammatory bowel disease. Inflamm Bowel Dis 16: 1411-1420, 2010.

16. Dolcet X, Llobet D, Pallares J and Matias-Guiu X: NF-kB in development and progression of human cancer. Virchows Arch 446: 475-482, 2005.

17. Onizawa M, Nagaishi $\mathrm{T}$, Kanai $\mathrm{T}$, et al: Signaling pathway via TNF-alpha/NF-kappaB in intestinal epithelial cells may be directly involved in colitis-associated carcinogenesis. Am J Physiol Gastrointest Liver Physiol 296: G850-G859, 2009.

18. Carothers AM, Davids JS, Damas BC and Bertagnolli MM: Persistent cyclooxygenase-2 inhibition downregulates NF- $\kappa B$, resulting in chronic intestinal inflammation in the Min/+ mouse model of colon tumorigenesis. Cancer Res 70: 4433-4442, 2010.

19. Shishodia $S$ and Aggar BB: Nuclear factor- $\kappa$ B: a friend or a foe in cancer? Biochem Pharmacol 68: 1071-1080, 2004.

20. Aggarwal BB: Nuclear factor- $\kappa B$ : the enemy within. Cancer Cell 6: 203-208, 2004.

21. Hassanzadeh P: Colorectal cancer and NF- $\kappa$ B signaling pathway. Gastroenterol Hepatol Bed Bench 4: 127-132, 2011.

22. Sakamoto K, Maeda S, Hikiba Y, et al: Constitutive NFkB activation in colorectal carcinoma plays a key role in angiogenesis, promoting tumor growth. Clin Cancer Res 15: 2248-2258, 2009.

23. Wang $S$, Liu Z, Wang L and Zhang X: NF- $\kappa B$ signaling pathway, inflammation and colorectal cancer. Cell Mol Immunol: 6: 327-334, 2009.

24. Osborn L, Kunkel S and Nabel GJ: Tumor necrosis factor alpha and interleukin-1 stimulate the human immunodeficiency virus enhancer by activation of the nuclear factor kappa B. Proc Natl Acad Sci USA 86: 2336-2340, 1989. 
25. Ward C, Chilvers ER, Lawson MF, et al: NF- $\kappa \mathrm{B}$ activation is a critical regulator of human granulocyte apoptosis in vitro. J Biol Chem 274: 4309-4318, 1999.

26. Grimm S, Bauer MK, Baeuerle PA and Schulze-Osthoff K: Bcl-2 down-regulates the activity of transcription factor NF-kappaB induced upon apoptosis. J Cell Biol 274: 13-23, 1999.

27. Van Antwerp DJ, Martin SJ, Kafri T, Green DR and Verma IM: Suppression of TNF-alpha-induced apoptosis by NF-kappaB. Science 274: 787-789, 1996.
28. Stark LA, Din FV, Zwacka RM and Dunlop MG: Aspirin-induced activation of the NF- $\kappa$ B signaling pathway: a novel mechanism for aspirin-mediated apoptosis in colon cancer cells. FASEB J 15 : 1273-1275, 2001.

29. Hanauer SB: Inflammatory bowel disease: epidemiology, pathogenesis, and therapeutic opportunities. Inflamm Bowel Dis 12 (Suppl 1): S3-S9, 2006. 